\author{
Crossing: The INPR Journal \\ Vol. II (2021): 81-93 \\ DOI: $10.21428 / 8766 \mathrm{eb} 43$. bo6aaaa 8
}

\title{
Jean-Luc Marion on the Question of Freedom
}

\author{
Taylor Knight, Institut Catholique de Paris, taylorscottknight@gmail.com. \\ Kristóf Oltvai, The University of Chicago, oltvai@uchicago.edu.
}

\section{A Philosophical Dialogue}

Taylor Knight: In his article, "Another Name for Liberty: Revelation, 'Objectivity,' and Intellectual Freedom in Barth and Marion," Kristóf Oltvai presents us with an interesting comparison of Marion and Barth. ${ }^{1}$ Indeed, it's much more than a comparison, for while Marion's phenomenology of givenness has often been paired with Barth's theology of Revelation, ${ }^{2}$ the originality and provocation of Oltvai's thesis is to argue that the irruption of an unconditioned gift (be it God himself, or, in Marion's case, any self-given saturated phenomenon) is a means by which the freedom of the human being is secured. This thesis flies in the face of the many accusations against these two thinkers, accusations which assert that the overwhelming nature of such a revelation or gift coerces the one who receives it. The receiver loses her freedom to choose for or against its legitimacy or to determine how it ought to be interpreted. In short, it abolishes the subject in the face of a dominating Other.

Oltvai, to the contrary, claims that a pleromatic revelation is precisely that on which an authentic hermeneutical freedom must be founded. This leads to his even

\footnotetext{
${ }^{1}$ Kristóf Oltvai, "Another Name for Liberty: Revelation, 'Objectivity,' and Intellectual Freedom in Barth and Marion," Open Theology 5, no. 1 (2019), https://doi.org/doi:10.1515/opth-2019-0036, https://doi.org/10.1515/opth-2019-0036.

${ }^{2}$ Now Marion has connected his own thought much more fully to Barth, first in Givenness and Revelation, (Oxford: Oxford University Press, 2016), and now in D'ailleurs, la révélation, (Paris: Grasset, 2020).
} 
more provocative conclusion: intellectual freedom is grounded in the Reformation doctrine of sola scriptura which is a doctrine that aims to clear away the accumulated dust of tradition in order to see what scripture really said - that is, it aims to interpret scripture from itself and not through the fog of the centuries.

Oltvai's article gets to what is essential: the question of freedom. Marion and Barth critique the totalizing power of philosophical rationality and its tendency to exclude anything that doesn't fit into its frameworks. That is to say, they critique its essential unfreedom. Yet their critics claim that they introduce a new form of bondage: the submission to the overwhelming Revelation which, worse than philosophical reason, does not even have a reason that justifies it. While Oltvai tries to address this critique by increasing Marion's debt to Barth and thus to the Protestant tradition, my approach to the question of freedom in Marion is quite the opposite. I aimed to show that Marion is much less of a Barthian than is usually supposed. Indeed I would suggest that Marion is even an ally of Barth's eternal nemesis, Erich Przywara.

I won't rehearse the arguments I've already laid out in my own articles, but it's worth reminding ourselves of the different cultural and historical situation that Marion lives, as a French Catholic, in comparison to how we situate religion in the anglophone world and, for that matter, in Germany. I'd be wary of using Marion's critique of his own tradition as an affirmation of a Barthian stance. The CatholicProtestant opposition is simply unknown in France precisely insofar as it is not a lived distinction. French Catholicism does not dwell under the shadow of a dominant Protestantism as American or English Catholics do. For all intents and purposes there is not even a minority Protestantism in France. Paul Ricœur's exceptional status only proves the rule. Even if filtered through German philosophy, the opposition that underlies all of Marion's philosophy is the French one: Catholicsecular. Again, it is the totalitarian threat, as much metaphysical as it is political, where the secular state has, since the time of Robespierre, threatened to close off the possibility of the religious. If there is something that resembles the Protestant purity principles of sola scriptura in Marion's metaphysics, it is only through the echoes that reverberate in Descartes' tabula rasa and Husserl's rallying cry of "back to the things themselves."

In general, I think that Marion's Barthian ties have been overstated by the scholarship. There's more in common with Aquinas than has been admitted. The distinction from Barth is hinted at through a couple of notes that mark an early admiration for Przywara's Analogia Entis, even if Marion never makes Przywara an explicit object of study. Oltvai, following Barth, puts liberalism and the analogy of being together as two sides of the same coin. One might counter this by saying that, no, in fact Barthian Calvinism and theological liberalism are two sides of the same coin. The more fruitful response, however, would be to take the approach of a martial 
artist. One must accept the full force of the attack to gather its energy and then use it in one's offensive.

Essentially, I agree with the polarity that Barth sets up. But I differ on two points. First, I don't think analogy's allegiance with liberalism is a strike against analogy. That its Protestant alter ego is theological liberalism doesn't negate its theological legitimacy nor does it make it idolatrous or ideological. Second, I see Marion as, in a certain way, one who is on the side as this liberalism-analogy duality and not against it. No doubt this is something of an eccentric interpretation of Marion, but it is not unjustified.

The most essential reason for my reading of Marion is that Marion sees that relation is primordial. As Oltvai cites from Being Given: "Individualized essence" no longer "precedes relation." (BG 268, cited at 442). Relation thus precedes not only the individual (the particular), but also the essence (the generic). Primordial relation is a necessarily indeterminate milieu insofar as determination has to do with either individuality or form, not relation. This milieu is pre-individual and pre-general. It lacks the specificity of a particular and the definitions that accompany a genus. When thinking about such a milieu, one cannot but recall Schelling who insists that the primordial state is a state of freedom, and that we should be more astonished at the fact that, after this initial freedom, everything is "caught in the web of reason." 3 In the milieu of relation before discrete existence, freedom is to be more expected than rationality. Freedom thus ontologically undergirds every form of reason and of structure.

No doubt Marion wants to retain the paradox which is contained in the idea of a primordial relation to the Wholly Other. This idea is paradoxical insofar as the Wholly Other is, by definition, that which is without relation. Historically, the best articulation of such a paradox has been the doctrine of the analogy of being, though perhaps Marion is offering us something a little different. The result of Marion's phenomenological analysis of such a primordial relation to the Wholly Other. I put Marion on the side of Barth's axis of evil (analogia entis-liberalism) because if he provides a way beyond it, it is only by passing through it that he reaches such an end. The passage "through" contorts and transforms the final product such we could not have reached the same insight were we not to have first accepted what lies "between," i.e., the analogy-liberalism polarity. To understand this transformation, we can focus on the question of interiority: the liberal "God within" and the Kantian limits on the knowable: the always already interior conditions of the possibility of experience.

Marion does not oppose these discourses directly, but shifts the terms of the debate, replacing interiority with intimacy. If interiority tends to imply a relation of identity (and thus idolatry), the intimacy Marion articulates is founded on

\footnotetext{
${ }^{3}$ Grundelegung der Positiven Philosophie, (Torino: Bottega d'Erasmo, 1972), 222.
} 
Augustine's interior intimo meo and a phenomenology of touch in which the most closely related terms cannot coincide, but instead create difference by means of the intimacy of their contact. If interiority implies an a priori relation, Marion articulates a relation that exists before the a priori is even possible: at a more fundamental level. It is for this reason that "freedom" cannot be related to a purely epistemological or hermeneutical realm. Moving through the Kantian separation of ontology and epistemology, Marion seems to move back towards their mutual intertwining, an intertwining which the most traditional Thomist knows, but which, in Marion's hands, is something quite different.

While Marion is no Rahner, he is more of a Rahner than a Barth, for he knows that it is only by working with Thomas and with Kant that he is able to go beyond them. After all, what they accomplished is not nothing. While Oltvai claims that "to refuse the closure of reason [is] the philosophical heritage of Protestantism," I find it hard to believe that Barth would embrace an open ontology like that of Rahner in which the human being is always available for a possible revelation. If Barth resists the closure of reason, does he not insist upon the closure of the human being - that she can only receive God through a revelation, and not through reason, precisely because she is radically closed and downward looking due to original sin? If in Marion, there is a structural openness to any possible phenomenon whatsoever, it is a derivative of Rahner, not of Barth.

Openness is not the ultimate issue with liberalism or with Catholic metaphysics. Openness does not of itself lead to nihilism and the exhaustion of being. What is problematic is a certain kind of openness, what we might call an openness without an underlying force. Such a purely passive openness lacks thickness. It is only the force of the pre-individuated milieu that can lead to decision. It is only such a force that can take from the indeterminable to make the determinate.

There is a certain critique of modernism that is shared between Marion and Barth. But I would strongly resist saying that their theological commitments would or could coincide. While Oltvai emphasizes "hermeneutical freedom" as the result of Revelation's unexpectedness and its pleroma, I wonder if Marion's philosophy is a critical philosophy at all. Certainly, the question of hermeneutics rarely enters the scene for Marion. While he's tried to respond to this seeming lacuna in his work, such a non-hermeneutical philosophy has a prestigious lineage that has little to do with fideism. Is it not better to take Marion's philosophy for what it is: not a hermeneutical or critical philosophy in the tradition of Kant, but an emergent formalism in the tradition of Schelling, a type of philosophy that only uses critique when it becomes necessary to dislodge an unwarranted belief in the eternal fixity of forms and the concomitant reification of forms as concepts? This reification is 
precisely what Oltvai wishes to address in his defense of Marion and Barth. At least in the case of Marion, I would take it in this altogether different direction.

Kristóf Oltvai: What Karl Rahner saw as the proper concept of truth and opposed to 'Greek' correspondence - namely, that it "consists first in letting our own personal essence come to the fore, positing ourselves without dissimulation, accepting ourselves and letting this authentic nature come to the fore...in the presence of others"4 - must today refocus our concept of freedom as well. For, in an effort to avoid fatalism, an 'arbitrarist' freedom has always been tempting for Christian thought: an act is only free if it could have been otherwise. "There can be no free gift unless the giver could withhold it." ${ }^{5}$ This decision's conceptual ramifications are admittedly quite complex, because although it intends to ward off naturalistic emanationism, a conflation of nature and grace often practically results. In theology proper, for example, we see this in the nominalist emphasis on God's potentia ordinata over absoluta, which returns with a vengeance in the Neo-Scholastic 'pure nature.' In anthropology, too, it can affirm man's absolutely free will while imprisoning him within an unimpeachable humanitas. Nonetheless, since Anselm (at least), philosophical theology has considered the 'Rahnerian' option, too; "when the will of God is said to do something of necessity, it is not actually coerced by necessity, but is maintaining itself by its own spontaneous unchangeability." "For this reason," in fact, "necessity is a misnomer (idcirco improprie dicitur necessitas)." Freedom is here self-consistency or self-expression, grounded in the determinate, and thus non-arbitrary, being of the acting subject.

The fundamental error of an excessively metaphysical theology is thus not that it says the word 'being,' but that it designates by this word an entirely abstract, indeterminate reality - and then has the temerity to name that reality 'God.' This maneuver, thought through to its logical end, not only threatens to return to the gnostic position of a meaningless universe, but also strips the knowledge of God of both possible and actual content. Karl Barth puts it strongly, but rightly: "This neutral Godhead, this pure and empty Godhead, and its claim to be true divinity, is the illusion of an abstract 'monotheism."”8 It depicts God's freedom as "the play of a

\footnotetext{
${ }^{4}$ Karl Rahner, The Trinity, trans. Joseph Donceel (New York: Herder \& Herder, 1997 [1967]), pp. 9596.

${ }^{5}$ Henri de Lubac, The Mystery of the Supernatural, trans. Rosemary Sheed (New York: Herder \& Herder, 1998 [1965]), p. 75.

${ }^{6}$ Anselm, Cur Deus Homo, II, 16a, 13. "Dei voluntas nulla cogitur necessitate, sed ipse se spontanea sua servat immutabilitate, quando dicitur aliquid necessitate facere."

${ }^{7}$ Id., II, 5, 10.

${ }^{8}$ Karl Barth, Church Dogmatics (CD) IV/1 (The Doctrine of Reconciliation), trans. G. W. Bromiley (New York: T\&T Clark, 1956 [1953]), §59, p. 203
} 
sovereign liberum arbitrium," theology, whose acts may always be but the vampire grins of a perhaps quite different Deus nudus et absconditus. I thus wholly agree with Taylor Knight that 'bad' versions of analogia entis, which "collapse...God into the world" in presumed contrast with "subtle[r]" doctrines, merit critique. However, I consider it insufficient to offer, as an alternative, as he seems to, a "radical heterogeneity" between God and creature. A 'God' totaliter aliter, completely inaccessible to thought, would only be the exact mirror image of the 'God' of being qua being whose concept has been stretched to its empty minimum. ${ }^{12}$ In neither case can we speak contentfully of God's being. This is why, "[f]or Przywara, the "constantly new experience of "still greater similarities"' is significantly only a moment in the rhythm of that 'pendulating middle-point' which is crossed, immediately and essentially, by the 'still greater distance.' As a pendulum" between absolute cataphasis and apophasis, "analogy never arrives at a conclusion" and "its symbol is the night"13 which betrays its agnosticism. To move beyond this aporia, we must be able to speak assuredly about God's being on the basis of God's acts. Theologically, this means doing away with the distinction between God's immanence and economy. Philosophically, it means thinking freedom as the selfexpression of being. 'Substance is subject' (Hegel).

I would argue that this tension between freedom as (1) ungrounded choice, liberum arbitrium and (2) as self-expression, remains unresolved for both Thomas Aquinas and Jean-Luc Marion, though both are aware of the difficulty. For Thomas, in fact, we can detect this theological rationale underlying the mature works' takingleave of thinking being as form in favor of being-in-act. ${ }^{14}$ The stress should be laid on act rather than on being, however, since Thomas's displeasure with his earlier formalist ontology is not only meant to avoid "confus[ing] creature with the creator and succumb to the univocity to which our conceptual processes incline us" and so

\footnotetext{
${ }^{9} I d .$, p. 195.

${ }^{10}$ Taylor Knight, "Real Relation and Saturated Phenomenon (Part One)," Neue Zeitschrift für Systematische Theologie und Religionsphilosophie 59, no. 3 (2017), p. 359.

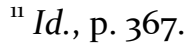

${ }^{12}$ The mature Barth emphatically rejects the formulation totaliter aliter for precisely this reason. See $C D$ IV/1, §59, p. 186 (emphasis mine): "We may believe that God can and must only be absolute in contrast to all that is relative, exalted in contrast to all that is lowly, active in contrast to all suffering, inviolable in contrast to all temptation, transcendent in contrast to all immanence, and divine in contrast to everything human, in short that He can and must be the only 'Wholly Other.' But such beliefs are shown to be quite untenable, and corrupt and pagan, by the fact that God does in fact be and do this in Jesus Christ."

${ }^{13}$ Eberhard Jüngel, God as the Mystery of the World, trans. R. David Nelson (New York: Bloomsbury T\&T Clark, 2014 [1977]), p. 285.

${ }^{14}$ Bernard Montagnes, The Doctrine of the Analogy of Being according to Thomas Aquinas, trans. E. M. Macierowski (Milwaukee: Marquette University Press, 2004 [1963]), p. 78.
} 
"safeguard the divine transcendence." ${ }^{15}$ Exclusively stressing this one goal can mislead us into thinking that being-in-act is Thomas's new definition of being-ingeneral. This would only be a new formalism, with a new conceptus entis. Rather, Thomas's actus purus moves toward thinking (created) being on the basis of God. "God is the same as His essence or nature (essentia vel natura)," there is no potentiality" - which is to essence as act is to being - "in Him essence does not differ from being (non sit aliud in eo essentia quam suum esse)." ${ }^{\prime 7}$ Furthermore, since God "acts by intellect and will (agat per modum intellectus et voluntatis)," "the essence of God is His intellect and will" (essentia Dei est eius intellegere et velle). ${ }^{18}$ This means that "names signifying relations following upon the action of the intellect and will (consequentes actionem intellectus vel voluntatis) are applied to God from eternity,"19 because these are essential relations. But God "produce[s] the creature...by His intellect and will (producit creaturas...per intellectum et per voluntatem)." ${ }^{20}$ The conclusion is clear: 'Creator' should be predicated of God ab ceterno, since the act of creation is a self-expression of God's eternal being. (Created) being would then be thought of as the relatum of this act, rather than from a generic conceptus entis that would needs bridge creator and creature. This is a clean freedom (2) schema.

Thomas, however, does not venture these last steps. Instead, he makes the distinction between virtual and real relation and claims that no "relation to the creature arises from [God's] nature." ${ }^{21}$ Names like "Savior" (!) and "Creator" must thus be "applied to God" only "temporally"22; to use another idiom, these predicates only hold economically, not immanently. The upshot for Thomas is that, if God's relation to creatures is, for God, only virtual, then God does not depend on creation. "[S]ince the goodness of God is perfect and can exist without other things (sine aliis)...it follows that for Him to will things other than Himself (alia a se velle) is not absolutely necessary." ${ }^{23}$ Freedom (1) has thus begun to crowd out freedom (2) because, if God's relation to creatures expressed God's essence, becoming is a moment of divine being. But becoming is $\mu \varepsilon \tau \alpha \beta 0 \lambda \eta$ - which, for metaphysics, deity must always exclude. Here Thomas's actus purus insight runs aground on his Aristotelian framework, as rather odd difficulties within the text attest. How can he juxtapose, for example, the

\footnotetext{
${ }^{15}$ Ibid.

${ }^{16}$ Summa theologiae (STh), I, q. 3, art. 3.

${ }^{17}$ STh, I. q. 3, art. 4.

${ }^{18}$ STh, I, q. 19, art. 4, ad 2. Emphasis mine.

${ }^{19}$ STh, I, q. 13, art. 7, ad 3.

${ }^{20}$ STh, I, q. 28, art. 1, ad 3.

${ }^{21}$ Ibid.

${ }^{22}$ STh, I, q. 13, art. 7, ad 3.

${ }^{23}$ STh, I, q. 19, art. 3.
} 
"necessity of [God's] nature" with "His intellect and will" ${ }^{24}$ when, earlier, it is precisely these facultative 'modes' in which God's actus, and thus God's essentia vel esse vel natura, allegedly operates? Or, even parsing this closer - and granting that, perhaps, necessitas ex suce naturce means necessitas absoluta here - how can we meaningfully distinguish necessitas absoluta and ex suppositione ${ }^{25}$ as regards a being who is in any case pure act, without accidents? ${ }^{26}$ Since God's actual "will cannot change," ${ }^{27}$ as Thomas admits, necessitas absoluta is only, at most, a limit-concept, a bare theoretical minimum that can serve as an epistemological guardrail against emanationism, but not as an ontological criterion for the creator-creature relation. Most surprising, though, is that Thomas chooses this explication of divine freedom instead of applying to God's will the distinction he draws in his discussion of God's knowledge, namely, that "although the knowledge of God is eternal," "that things should be eternal was not in the knowledge of God." Hence, "it does not follows that creatures are eternal." ${ }^{28}$ Could not God, analogously, eternally will that things be without willing them to be eternal? This would seem to preserve the creator-creature relation as being necessary and real in God, as well as in the creature, without divinizing the latter.

What is at stake in this debate is a point Thomas puts in the mouths of his objectors: did not God "from eternity...[know] and love the creature, according to the word: 'I have loved thee with an everlasting love' (Jer. 31:3)"29? The Franciscans' and Henry of Ghent's taking-issue with virtual relation, although they did undoubtedly "want...a closer relation of the creature to God,"30 as Knight rightly notes, should also be read in light of this question. Is God's love for the creature essential to God? Furthermore, does the desire to answer affirmatively to that question underlie, say, Duns Scotus's doctrine of the univocity of being? If so, a more sympathetic historical-theological engagement with the problem of univocity may need to be written, rather than one that serves mainly to exonerate Thomas while placing the blame for excogitating 'representationalism' on some later thinker. This history, likely part and parcel of the one "of charity" ${ }^{31}$ Marion calls for, would attempt to trace the points at which a genuinely theological ontology, thinking being a Deo

\footnotetext{
${ }^{24}$ STh, I, q. 28 , art. 1 , ad 3.

${ }^{25}$ STh, I, q. 19, art. 3.

${ }^{26}$ STh, I, q. 3, art. 6.

${ }^{27}$ STh, I, q. 19, art. 3.

${ }^{28}$ STh, I, q. 14, art. 8, ad 2. Emphasis mine.

${ }^{29}$ STh, I, q. 13, art. 7, obj. 3.

${ }^{30}$ Knight, "Real Relation and Saturated Phenomenon (Part One)," p. 363.

${ }^{31}$ Jean-Luc Marion, On Descartes' Metaphysical Prism: The Constitution and Limits of Onto-TheoLogy in Cartesian Thought, trans. Jeffrey L. Kosky (Chicago: University of Chicago Press, 1999 [1986]), p. 352 .
} 
as the self-expression of divine love, gave way to "a doctrine of being drawn up on the basis of a general ontological conception within which the being of God (as highest being, as being-itself, etc.) would be treated in its place. ${ }^{.32}$ It would also attend to the ways in which ontology, epistemology, and theories of (both divine and human) freedom and love form complexly interacting through-lines in Christian thought from Thomas, through nominalism, to Luther and Descartes. Such a history would expand the legitimate utility of the critique of ontotheology without reducing the emergence of modernity to the problem of the knowledge (or not) of God, which can marginalize the intersection of that theme with other debates, such as those about soteriology, in the late-medieval context.

Marion himself raises, in his interpretation of Pascal, this possibility: of rescuing the word 'being,' when thought a caritate, from metaphysics. "Being, which here signifies a way of Being and beingness, must not be referred to the order of metaphysics, but to that of charity." 33 Such an 'ontology of love,' as a material determination, cannot, however, be derived from the formal phenomenological structure of événementialité. Materially, events are too capricious: they include debilitating traumas, "life-altering accidents" and wars, as well as (potential) joys like "falling in love," ${ }^{34}$ an ambiguity Knight himself emphasizes. Formally - and completely logically so, since 'event' is but a phenomenological-structural term they thus are empty: "a negative certainty of infinite distance without a positive content." ${ }^{35}$ Strictly philosophically, these two determinations are legitimate and lead to, as I argue in the piece Knight responds to, certain epistemological upshots in and of themselves. If reflexively 'theologized,' however - which means confusing their phenomenological structure with their phenomenal content -, the former determination leads to a divine liberum arbitrium, the latter to a human one. While I do not think Marion's work can be fairly interpreted as supporting the first, textual evidence exists for the second. This remains, in my view, a genuine tension in Marion's thought, since it seems to resurrect a metaphysical voluntas at the same moment that, in l'adonné - that non- or anti-subject - it seeks to think the person prior to her faculties. I would therefore argue that if "[f]aith...bring[s] the understanding to decide to will or not to will to accept the coming of God," ${ }^{36}$ we have

\footnotetext{
${ }^{32}$ Eberhard Jüngel, God's Being is in Becoming: The Trinitarian Being of God in the Theology of Karl Barth, trans. John Webster (New York: Bloomsbury T\&T Clark, 2014 [1964]), p. 76. Emphasis mine.

${ }^{33}$ Marion, On Descartes' Metaphysical Prism, p. 341.

${ }^{34}$ Taylor Knight, "Saturated Phenomenon and Real Relation (Part Two)," Neue Zeitschrift für Systematische Theologie und Religionsphilosophie 59, no. 4 (2017), p. 618.

${ }^{35}$ Id., p. 627.

${ }^{36}$ Jean-Luc Marion, Givenness and Revelation, trans. Stephen E. Lewis (Oxford: Oxford University. Press, 2016), p. 117.
} 
still not thought givenness radically enough - as Calvin did when he thought this, theologically, as 'irresistible grace.'

"[T] o ask, 'Can I love first?' rather than, 'Does anyone out there love me?"”37 might thus be proper phenomenological advice for human relationships (indeed, any lover would confirm it), but it cannot authorize "the nonmetaphysical thought of Being" ${ }^{18}$ made actual by God's love for us and revealed in the factum Christi. Marion is at least partially sympathetic to this view. "To become a self, I need to be neither seen, nor thought, nor known, but nothing less than loved" 39 ; "the ego, to be loved as a me...cannot remain autonomous, since another gaze that loves it is necessary to it," indeed "suffice[s] for defining the only possible addressee of a love, the unsubstitutable person" 40 - these are his own interpretations of Pascal. "He first loved us" (1 Jn. 4:19). Freedom (2), the freedom to express oneself, seems to more so conceptually follow from this factum of divine love than from an "incommensurability of orders." ${ }^{41}$ For although the latter does indeed free us from the "extrinsic imposition" 42 efficient causality works and so grants freedom (1), my worry is that final causality's compulsion still hovers ominously in the background here. "[O]n the sole condition that I..." ${ }^{43}$ - such conditional loving still seems trapped in the economy of being, drawn automatically, even mechanistically, to the beloved's qualities. But is there not "but one single proof of love - to give without return or change of recovery, and thus to be able to lose and, eventually, to be lost in love" 44 ? The experience of Christian freedom thinks this 'single proof not only of the love of man for God but, eminently and more originally, of the love of God for man. God's sovereign self-expression of love would thus not pose a threat to free human selfexpression since the former, precisely because sovereign, would be unconditioned and indeed unconditional.

Knight: After I wrote these articles on Marion, I plunged more deeply into the great and enigmatic thinker, Nicholas of Cusa, whose work, while not the primary influence on Marion, was at least central to my interpretation and whose "postnominalist realism" (John Milbank) offers a different way forward from Aquinas than, say, Calvin in the next century.

${ }^{37}$ Jean-Luc Marion, The Erotic Phenomenon, trans. Stephen E. Lewis (Chicago: University of Chicago Press, 2007 [2003]), p. 71.

${ }^{38}$ Marion, On Descartes' Metaphysical Prism, p. 342.

${ }^{39} I d$., p. 324.

${ }^{40} I d$., p. 325.

${ }^{41}$ Knight, "Saturated Phenomenon and Real Relation (Part Two)," p. 627.

${ }^{42}$ Ibid.

${ }^{43}$ Marion, On Descartes' Metaphysical Prism, p. 333.

${ }^{44}$ Marion, The Erotic Phenomenon, p. 71. 
I can thus, after reading Oltvai's response to my articles, only emphasize the points that I had already been making and will resist getting bogged down in the Kantian minutiae which only seem to distract from the essence of the matter. No doubt Marion still works within the Kantian conceptual framework (as we all must), but if his work shows anything, it is that Kant's conditions of possibility no longer apply when we try to conceive either the relation of creation or the possibility/fact of revelation. ${ }^{45}$ And so, we need to turn to other sources.

I do not think Christian ontology has fully integrated the insights of Nicholas of Cusa, this liminal philosopher hovering between the medieval and modern world but belonging to neither: a true philosopher "according to the order of Melchizedek," with neither philosophical genealogy (belonging to no medieval school) nor philosophical progeny (founding no modern ideology). His singularity is no doubt an exaggeration, but the exaggeration is only slight, for the philosophy Cusa articulates has profound implications that have gone largely untested.

Cusa's logic of the maximum is a logic that takes over at the site where the logic of similarity, of comparison and contrast, no longer applies. When we move from "greater" to "greatest" a quantum leap occurs such that the maximal breaks free of the series and jumps to another domain entirely, which has its own logic and its own organization. To speak of the maximum in this way does not in the least imply the destruction of all order and of all content. It is simply the installation of a new order without cancelling out the old. The infinite or maximum is precisely at this site of relation between two incommensurable things. The infinite is relation. It is not what is absolutely separated. It is the electricity that shoots back and forth between two things.

Far from leading us towards pure abstractions or categories, the logic of the maximum is simply the logic of the body and of touch. When the hand reaches out and touches another's body, there is absolutely no confusion or fusion between the two except that of the electric shock. In contact, the infinite abyss between myself and the other is created and energized. Contact even coincides with absolute difference and differentiation. Intimate relation and infinite distance: these things do not have to be opposed.

In light of such a logic of the maximum the old debates that pit human freedom and divine providence against each other seem obsolete. Even as Oltvai rightly opposes the liberty of "choice" ("arbitrarist freedom"), he remains too firmly entrenched in an epistemological interpretation of what freedom can or ought to be, preoccupied as he is with the idea of God as a "content" of revelation that he contrasts to an "empty" formalism. But the question of human freedom needs to become an ontological one: that created being is maximally related to God's being and that this

\footnotetext{
${ }^{45}$ With respect to revelation, possibility and fact would amount to the same thing.
} 
maximal relation-being superlative and not comparative-coincides with a maximum freedom. This would mean that the deepest acts of freedom are no longer concerned with knowing, interpreting, and choosing. Instead freedom is constituted in acts of making. Our good friend and colleague, Romilo Knežević, has taken us down this path in his excellent new book, Homo Theurgos: Freedom according to John Zizioulas and Nikolai Berdyaev (Paris: Cerf, 2020). Perhaps the largely Orthodox register of this work, free of the nature/grace debates of Western theology, provides a clearer way towards articulating ontological freedom. But there are Western thinkers who Knežević deems essential (among them Schelling, Jung, and Nietszche). In my view, Nicholas of Cusa and Marion (if my interpretation is valid) ought to be added to that number.

Oltvai: Our dialogue has confirmed Marion's fecundity as a thinker, what with intellectual-historical giants like Barth and Schelling serving as our analyses' endpoints. Knight's turn to Schelling's concepts of force and freedom is fascinating, and he should consider developing this point of contact further. In the space allotted, I will restrict myself to two rebuttals: one genealogical, the second theological.

I agree, first, that Marion's immediate context, i.e., the enduring French debates surrounding laïcité, impact his oeuvre. I would dispute, however, any final distinction between these debates, especially under the rubric of 'totalitarianism,' and those about sola scriptura in Protestant-Catholic polemics. The magisterial Reformers were aware that their doctrine, though it foremost opposed the papacy's purely spiritual totalitarianism, would spur a political-theological transformation in favor of individual freedom. In reaction to this, Tridentine Neo-Scholasticism notably the Spanish Jesuits - doubled down on integralism, which was then halfsecularized and transposed onto the body of the sovereign in Hobbes. Rousseau then democratized Hobbesian sovereignty through the notion of a 'general will,' but the conceptual architecture of this democracy differs from the Protestant one grounded in the 'priesthood of all believers.' Now, since Robespierre's "authoritarian populism" legitimated itself on Rousseau's general will concept, ${ }^{46}$ the disputes about religion within French republicanism are genealogically linked to the Reformation. This is buttressed, on Barth's side, by his lifelong - and personal, as at Barmen - resistance to political totalitarianism. His use of the Reformers to critique ideology - socialism in the Römerbrief, Nazism in his mature work - is, I think, a more significant through-line in his work than any battle against Catholicism, although, for the reasons I've just outlined, we can see them as connected.

${ }^{46}$ Jonathan Israel, The Enlightenment that Failed: Ideas, Revolution, and Democratic Defeat, 1748 1830 (Oxon.: Oxford University. Press, 2019), p. 468 ff. 
My theological rebuttal regards 'openness.' I agree that Marion's gestures beyond subjectivity (l'adonné, etc.) share analogues with Rahner's concept of protorevelation. What I would push back on is the conclusion that such an openness better grounds human freedom than what Barth means by revelation. For Barth, as it was for the Reformers, God's revelation to us is not indeterminate or arbitrary. It is Jesus Christ: God with and for us. Barth's objection to Rahner, which I share, would be that his concept of 'openness' to 'mystery,' as he formulates it in the Grundkurs, suggests that 'the mysterious' as such, or 'the numinous' (Otto) as such, constitutes the human experience of God, an experience hardly distinguishable from that of contentless, sovereign power. Divinizing such power tempts all "open ontologies," to use Knight's phrase, which is why Barth insists that theology must presuppose the fact of revelation, and not only its possibility. 